\title{
REVITALISASI GERABAH TRADISIONAL GALOGANDANG DENGAN TEKNIK BATIK MENJADI PRODUK ESTETIK
}

\author{
Izan Qomarats ${ }^{1)}$, Hendra'2), Rahmad Washinton ${ }^{3)}$ \\ 1)2)3)Program Studi Desain Komunikasi Visual, Fakultas Seni Rupa Dan Desain \\ Institut Seni Indonesia Padangpanjang \\ Jln. Bahder Johan Padangpanjang Sumatera Barat Kodepos 27128 \\ Email : izanqomarats1508@gmail.com ${ }^{1)}$, doankhendra7@gmail.com ${ }^{2)}$ \\ rahmad.washinton@gmail.com ${ }^{3)}$
}

\begin{abstract}
ABSTRAK
Pelatihan desain gerabah tradisional Galogandang dilakukan untuk menumbuhkan kebanggaan generasi muda terhadap produk budaya lokal. Apalagi pembuatan gerabah di Galogandang sekarang ini hanya didominasi oleh ibu-ibu yang lanjut usia. Sedangkan belum tampak adanya generasi muda yang berminat melanjutkan dan mengembangkannya. Jika hal ini dibiarkan berlanjut, maka lama kelamaan gerabah di Galogandang bisa tinggal sejarah. Salah satu upaya untuk itu adalah dengan pelatihan desain gerabah dengan motif batik khas Minangkabau. Kegiatan pelatihan yang tergolong baru untuk wilayah Sumatera Barat ini ditujukan untuk mempopulerkan gerabah tradisional yang dipadukan dengan motif kontemporer yaitu motif batik. Kegiatan ini dinilai efektif untuk mendongkrak popularitas gerabah tradisi dan mempromosikan motif batik khas Minangkabau yang belum banyak dikenal masyarakat. Pelatihan ini mengajarkan bagaimana membuat motif batik khas Minangkabau dengan menggunakan canting batik sehingga produk yang dihasilkan lebih menarik. Mendekorasi gerabah dengan teknik ini bisa menjadi solusi bagi pengrajin gerabah dalam memasarkan produk gerabahnya yang selama ini dibuat tanpa ada motif hias. Dengan kegiatan ini diharapkan akan bisa mempopulerkan kembali gerabah Galogandang dengan wajah baru yang lebih menarik. Kedepannya pengrajin juga bisa membuat beragam bentuk desain baru dari gerabah untuk disesuaikan dengan konsep motif kreasi yang dibuat.
\end{abstract}

Kata kunci : Gerabah, Desain, Motif Batik

\section{PENDAHULUAN}

\subsection{Latar belakang}

Kabupaten Tanah Datar dikenal sebagai provinsi yang memiliki potensi pariwisata budaya yang sangat menjanjikan. Hal itu dapat dilihat dengan adanya Istano Basa Pagaruyuang yang berdiri megah dan menjadi andalan pariwisata di Kabupaten Tanah Datar. Dengan tingginya jumlah wisatawan yang datang maka potensi pengembangan produk cendramata sangat menjanjikan. Apalagi selama ini produk cendramata khas Pagaruyuang belum ada yang dibuat oleh masyarakat sekitar yang berorientasikan kebudayaan lokal masyarakat sekitar. Padahal potensi membuat cendramata khas Pagaruyuang bisa menambah penghasilan dari masyarakat sekitarnya.

Jorong Galogandang yang terletak di Nagari III Koto Kecamatan Rambatan dikenal sebagai salah satu daerah penghasil kerajinan gerabah tradisional untuk wilayah Kabupaten Tanah Datar. Berbagai bentuk gerabah seperti periuk, guci dan lain sebagainya dihasilkan oleh penduduk untuk berbagai keperluan. Namun seiring perkembangan zaman, jumlah pengrajin gerabah di Galogandang menurun drastis. Salah satu penyebabnya adalah kurangnya minat dari generasi muda untuk melanjutkan usaha membuat gerabah, dan lebih memilih untuk pergi merantau keluar daerah. Fenomena ini terus berlanjut sehingga pengrajin yang tinggal sekarang hanya mereka yang tua saja. Sedangkan anak-anak mereka tidak dikenalkan dengan kerajinan gerabah ini yang beberapa dasawarsa yang lalu pernah menjadi pekerjaan mayoritas penduduk Galogandang. Jika hal ini terus berlanjut, diperkirakan dalam beberapa tahun kedepan akan sulit menemukan kerajinan gerabah yang dibuat oleh warga Galogandang. Padahal produk gerabah Galogandang sebagai produk budaya khas Tanah Datar memiliki potensi untuk dikembangkan menjadi produk unggulan jika dikemas secara baik. Hal ini yang perlu diberikan perhatian lebih dimana jika gerabah tradisional tersebut dikreasikan dengan menarik, 
bisa menjadi produk souvenir khas Tanah Datar yang bisa dipasarkan didaerah wisata seperti Pagaruyuang.
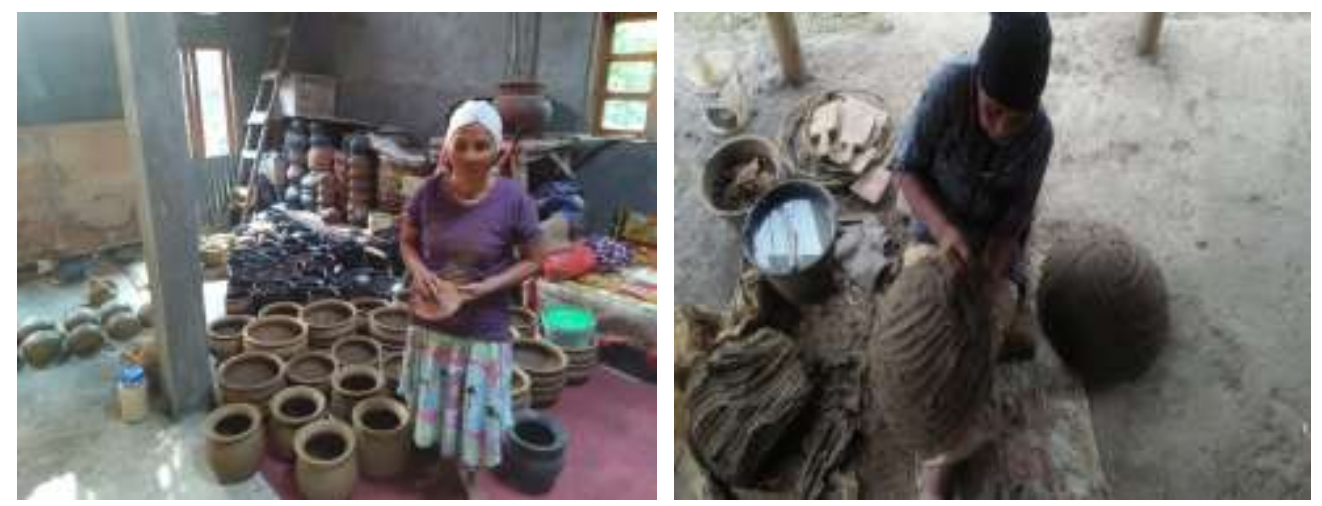

Gambar 1. Kegiatan Perempuan Galogandang Membuat Gerabah

Untuk menumbuhkan minat dan kecintaan dari generasi muda terhadap gerabah Galogandang tersebut, maka perlu diadakan suatu kegiatan pelatihan desain gerabah dengan motif batik bagi generasi muda di Galogandang. Motif batik yang menjadi dekorasi dari produk gerabah tersebut didesain dari kreasi dari motif batik khas Minangkabau yang sedang dikembangkan oleh pemerintah provinsi Sumatera Barat. Desain adalah suatu perwujudan dari suatu gagasan atau hasil karya yang bersifat inovatif dan kreatif dari seseorang atau lebih untuk menciptakan sesuatu pola tertentu dengan cara menentukan serta memperincikan setiap bagian elemen atau komponen dari pola tersebut serta antara hubungannya satu dengan yang lain, sehingga tersusun suatu pola dari bentuk yang merupakan suatu keseluruhan. (Prawira, 1983:1). Selain itu motif batik khas Minangkabau memang sedang digalakkan dan dikembangkan oleh Pemprov Sumatera Barat sebagai ikon budaya Minang. ( Wawancara dengan Rionald, Sekretaris Dekranasda Provinsi Sumatera Barat: Desember 2016).

Hal ini sejalan dengan program pemerintah provinsi yang ingin mengembangkan kerajinan batik dengan desain khas Minangkabau. Motif batik yang biasanya diaplikasikan pada baju dan pakaian tersebut, nantinya akan dikreasikan dan diaplikasikan di gerabah tradisional Galogandang. Didaerah jawa, kerajinan gerabah tradisional sudah mulai dikreasikan dengan motif batik sehingga lebih bisa menarik perhatian konsumen. Tentunya gerabah dengan motif batik tersebut merupakan produk yang jarang ditemui di pasaran dan sangat menarik bagi konsumen. Produk seperti ini nantinyya bisa dipasarkan didaerah pusat wisata seperi Pagaruyuang yang lokasinya tidak terlalu jauh dari Jorong Galogandang. Dengan kreativitas mendesain gerabah dengan motif batik tersebut, maka pengrajin bisa meningkatkan pendapatannya disamping juga turut mengembangkan produk gerabah tradisional Galogandang. Kegiatan pelatihan seperti ini dinilai lebih tepat sasaran dan bisa dioptimalkan bagi generasi muda yang tertarik untuk memajukan gerabah tradisional Galogandang.

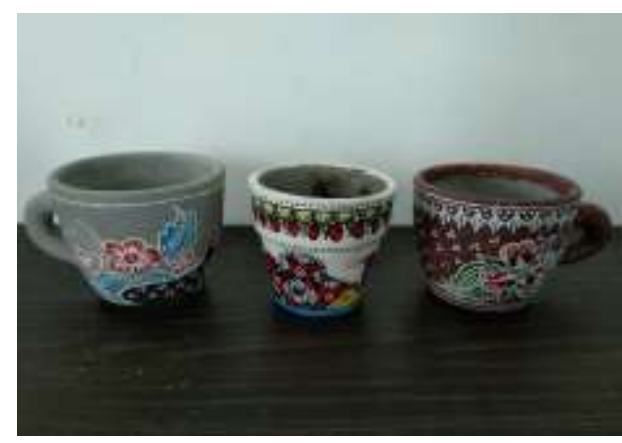

Gambar 2. Gerabah tradisional yang diberi motif batik

Kegiatan pelatihan ini ditujukan diberikan kepada generasi muda Galogandang yang nantinya diharapkan akan terjadi sinergi antara generasi muda Galogandang dan pengrajin yang ada. Tujuannya untuk meningkatkan fungsi dan harga dari gerabah tersebut. Gerabah yang selama ini biasanya digunakan untuk tempat memasak gulai atau obat tradisional, akan dirubah fungsinya menjadi souvenir yang menarik dan menjadi ikon dari Galogandang itu sendir. Gerabah tradisional tesebut 
akan dijadikan cendramata dan desain dengan motif khas Minangkabau yang tentunya bisa menjadi salah satu souvenir unik dan andalan bagi wisatawan yang datang ke Pagaruyuang. Dari uraian diatas maka kegiatan pelatihan gerabah ini sangat penting untuk dilaksanakan, mengingat potensi gerabah tradisional Galogandang untuk dikembangkan terbuka lebar. Selain itu kegiatan ini juga turut mempopulerkan batik khas Minangkabau kepada masyarakat luas.

\subsection{Permasalahan Mitra}

Berdasarkan analisis situasi diatas maka ada beberapa poin permasalahan yang dihadapi oleh mitra yaitu :

1. Kurangnya minat generasi muda Galogandang untuk mengembangkan gerabah tradisional Galogandang sehingga bentuk dan jenis produk yang dihasilkan selalu sama sejak puluhan tahun yang lalu.

2. Kurangnya pengetahuan dan wawasan dari pengrajin mengenai cara pengembangan produk gerabah tradisional tersebut.

3. Belum adanya kegiatan pelatihan tentang upaya pengembangan gerabah Galogandang serta potensi pengembangan usahanya yang diterima oleh masyarakat sekitar yang berorientasi ekonomi kreatif.

Dari permasalahan diatas dapat dilihat bahwa perlunya upaya untuk menggugah perhatian dari generasi muda terhadap gerabah Galogandang itu sendiri. Hal ini menunjukkan bahwa gerabah tersebut memiliki potensi yang besar untuk dikembangkan jika ditangani dengan serius dan mengedepankan konsep kreativitas dalam pelaksanaannya.

\subsection{Tujuan Kegiatan}

Adapun tujuan dari kegiatan ini adalah untuk:

1. Meningkatkan popularitas gerabah tradisional Galogandang

2. Meningkatkan pendapatan masyarakat sekitar.

3. Mempopulerkan motif batik khas Minangkabau yang sedang dikembangkan oleh pemerintah daerah.

4. Sebagai keberlanjutan dari kegiatan pengabdian desain gerbag yang sukses dilaksanakan di Sekolah sekitar Galogandang.

Justifikasi dari kegiatan pengabdian yang dilaksanakan Jorong Galogandang adalah sebagai salah satu bentuk social responsibility karena pengabdian adalah bagian penting dari Tridharma Perguruan tinggi untuk berbagi ilmu kepada masyarakat. Dengan adanya proses berbagi pengetahuan tersebut diharapkan masyarakat akan bisa meningkatkan taraf hidupnya menjadi lebih baik. Peluang ekonomi sangat terbuka dengan memaksimalkan finishing dari gerabah tradisi sehingga fungsinya berubah dari sekedar menjadi periuk untuk diolah menjadi produk souvenir. (Sudana, 2014:3)

\subsection{Masalah}

Pengrajin tradisional Galogandang mendapatkan keahlian membuat gerabah secara turun temurun. Hal ini sudah dimulai semenjak puluhan tahun yang lalu dimana keahlian membuat gerabah diwariskan secara turun temurun. Hal ini seperti yang disampaikan oleh Usnidar ( 54 tahun) bahwa dia mewarisi kemampuan membuat gerabah dari orangtuanya yang juga membuat gerabah. Namun sekarang fenomena seperti itu mulai ditinggalkan dimana anaknya tak mau mengikuti jejaknya menjadi pengrajin gerabah. Dua orang anaknya sudah merantau semenjak lulus SLTA dan memilih mencari profesi lain yang lebih menajnjikan daripada menjadi pengrajin gerabah. Anak laki-lakinya memilih merantau dan berdagang sedangkan anak perempuannya juga mengikuti suaminya di Medan. Beliau mengatakan bahwa anaknya tak ada yang mau mengikuti jejaknya menjadi pengraji gerabah dikarenakan secara ekonomi, profesi membuat gerabah tidak bisa mencukupi butuhan hidup seharihari. Hal ini dikarenakan harga gerabah berbentuk balango ditingkat pengrajin hanya sekitar Rp. 7.000 sampai Rp. 12.000. Harga ini dirasakan tidak sebanding dengan waktu pembuatan yang relatif lama dan proses pembuatannya yang cukup melelahkan.

Kondisi seperti ini yang membuat rata-rata pengrajin gerabah sekarang hanya wanita usia 40 tahun keatas yang yang menjadikan pekerjaan ini sebagai pengisi waktu luang. Persoalan yang telah berlangsung bertahun tahun ini tentunya mengancam eksistensi dan keberlangsungan kerajinan gerabah Galogandang. Jika fenomena ini terus dibiarkan, bisa jadi sepuluh atau duapuluh tahun kedepan kerajinan gerabah Galogandang hanya tinggal nama. Perlu diupayakan suatu kegiatan untuk 
menggugah ketertarikan dan kebanggaan dari generasi muda Galogandang terhadap budaya lokal tersebut. Perlu diupayakan suatu startegi kegiatan untuk menumbuhkan minat dan ketertarikan dari generasi muda Galogandang terhadap produk gerabah tersebut. Salah satunya adalah dengan membuat kegiatan pelatihan desain gerabah dengan motif batik yang akan menambah nilai jual dari gerabah tersebut.

Batik Mempunyai dua komponen utama yaitu warna dan garis. Kedua komponen inilah yang membentuk batik menjadi indah dan menawan. (Wulandari, 2011: 76). Jadi pada intinya, selama dua komponen utama tersebut ada, tidaklah menjadi masalah apapun media yang digunakan, baik itu kain ataupun gerabah dan media lainnya yang mungkin bisa diaplikasikan untuk motif batik itu sendiri. Penerapan motif batik pada produk gerabah tersebut akan meningkatkan nilai jual dari gerabah yang ada. Gerabah tersebut bisa menjadi produk cendramata yang menarik dan menjadi ikon unik Galogandang.

\section{METODE}

Pelatihan yang dilakukan terhadap engrajin gerabah Galogandang bertujuan untuk meningkatkan kemampuan dan wawasan mereka. Menurut Amstrong (1988: 208) pelatihan adalah kegiatan untuk mengisi kesenjangan antara apa yang dapat dikerjakan seseorang dan siapa yang seharusnya mengerjakannya. Pelaksanaan kegiatan ini dimulai dengan diskusi yang meilbatkan pengrajin terkait kendala yag dihadapi dalam mengembangkan usaha gerabah tradisional Galogandang ini. Diskusi ini juga bertujuan untuk mengetahui segala bentuk permasalahan terkait keberlangsungan usaha gerabah Galogandang. Dari diskusi ini nantinya bisa dirancang metode pelaksanaan kegiatan yang lebih efektif dan efisien guna mengembangkan usaha gerabah tradisional Galogandang ini.

Setelah diskusi maka dilanjutkan demonstrasi dimana bertujuan untuk memperlihatkan proses dari mendesain dan aplikasi desain ke media gerabah. Untuk langkah awal dicontohkan bagaimana membuat desain pada media kertas sehingga lebih mudah untuk diikuti oleh peserta. Setelah itu baru dilanjutkan dengan mengaplikasikan desain dari media kertas ke gerabah yang memiliki permukaan tidak datar dan tentunya akan lebih sulit daripada membuat desain diatas media kertas. Pada proses ini digunakan beberapa teknik yaitu teknik aplikasi desain batik dengan kuas cat air dan aplikasi desain batik dengan membatik langsung diatas permukaan gerabah dengan menggunakan canting dan pewarnanya menggunakan malam. Teknik dan metode ini yang perlu ditekankan dan diperkenalkan kepada peserta karena masih baru dan belum begitu populer dimasyarakat.

Proses selanjutnya adalah eksperimen dari berbagai bentuk motif batik khas Minangkabau yang akan diaplikasikan di media gerabah. Pemilihan jenis motif dan kesesuaian dengan bentuk gerabah juga menjadi hal yang harus dipertimbangkan. Tujuannya agar gerabah yang diaplikasikan motif batik tersebut memiliki nilai estetis dan filosofi yang kuat sehingga memiliki nilai jual yang tinggi juga. Proses yang terakhir adalah metode resitasi atau pemberian tugas kepada peserta untuk muali membuat gerabah dengan desain batik tersebut. Setiap langkah dan proses yang dilakukan harus didampngi sehingga tujuan dari kegiatan ini dapat tercapai denga baik dan peserta bisa memahami setiap proses membatik diatas gerabah tersebut dengan baik.

\subsection{Teknik Pengumpulan Data}

Untuk memperoleh data yang akurat dilapangan mengenai kondisi yang terjadi dilaksanakan beberapa metode antara lain :

\subsubsection{Metode Observasi}

Kegiatan ini bertujuan untuk mendapatkan data langsung dan riil dari lapangan. Dengan metode ini penulis melakukan pengamatan awal terlebihdahulu mengenai kondisi gerabah Galogandang dan bagaimana tingkat apresiasi masyarakat sekitar terhadap kerajinan itu sendiri.

\subsubsection{Metode Wawancara}

Yang bertujuan untuk mendapatkan data langsung dari narasumber yang berhubungan dengan data yang ingin diperoleh. Metode wawancara ini dilakukan kepada beberapa narasumber yang berbeda profesi dan bidangnya sehingga akan memperoleh data yang lebih akurat.

\subsubsection{Pengumpulan Data}

Yang dilakukan dengan mendokumentasikan data tersebut melalui foto atau video. Data dari foto dan video nantinya akan menggambarkan lebih jelas tentang kondisi yang ada dilapangan. 


\subsubsection{Studi Pustaka}

Yang dilakukan mendapatkan data dan informasi tambahanan dari buku atau artikel yang mendukung. Studi pustaka perlu dilakukan untuk mendukung keilmiahan data dan pada saat analisis data nantinya.

\section{PEMBAHASAN}

\subsection{Koordinasi Kegiatan}

Langkah koordinasi yang dimaksud adalah penyampaian rencana kegiatan ini oleh ketua tim pengabdi kepengrajin. Koordinasi dengan pengrajin sangat perlu untuk dilaksanakan karena mereka adalah pelaku seni yang nantinya akan melanjutkan pelaksanaan hasil pengabdian. Koordinasi juga dilakukan dengan tim pelaksana pengabdian yang bertujuan untuk terlaksananya kegiatan dengan sebaik mungkin. Dari kordinasi ini nantinya akan tergambarkan langkah pelaksanaan kegiatan pengabdian ini.

\subsection{Pelaksanaan Kegiatan}

Kegiatan yang dilaksanakan untuk menumbuhkan minat generasi muda Galogandang terhadap gerabah adalah dengan pelatihan desain. Agar kegiatan yang direncanakan ini dapat terlaksana dengan baik dan mencapai hasil yang diharapkan, perlu dirancang suatu proses atau metode pelaksanaan yang tepat dan sesuai dengan tujuan yang dibuat. Metode pelaksanaan kegiatan pelatihan ini adalah eksplorasi media dan model sehingga didapatkan hasil produk yang maksimal.

Metode pelaksanaan kegiatan adalah dengan cara yang mudah dipahami oleh pengrajin. Sebagai bentuk kegiatan untuk menumbuhkan kecintaan generasi muda terhadap gerabah Galogandang, maka peserta dalam kegiatan pelatihan ini melibatkan ibu-ibu dan anak-anak mereka. Hal ini agar adanya proses transfer ilmu pengetahuan kepada generasi muda yang nantinya akan melanjutkan usaha gerabah tradisional Galogandang ini. Dalam pelaksanaan kegiatan pelatihan ini melibatkan kelompok pengrajin Citra Balango yang merupakan salah satu kelompok usaha gerabah yang ada. Kegiatan pelatihan ini dilaksanakan dirumah salah seorang pengrajin yang bernama Usidar. Kegiatan dimulai dengan melaksanakan diskusi dengan pengrajin mengenai kegiatan yang akan dilaksanakan. Diskusi ini bertujuan untuk memberikan penjelasan dan pemahaman kepada peserta mengenai kegiatan yang akan dilaksanakan. Diskusi ini menjelaskan mengenai tujuan dari mendesain gerabah dengan motif batik adalah untuk meningkatkan nilai jual dan harga dari produk gerabah tersebut. Selain itu gerabah tradisi ini juga akan berubah fungsi dari periuk yang digunakan untuk memasak menjadi produk kriya seni yang memiliki nilai esetetika dan nilai jual lebih tinggi. Dalam diskusi ini juga dibawa contoh produk gerabah yang telah didesain dengan motif batik sehingga nilai jualnya lebih tinggi. Dari diskusi singkat tersebut, peserta lebih memahami bagaimana potensi pengembangan usaha gerabah tradisional tersebut sehingga menjadi produk dengan nilai jual lebih tinggi.

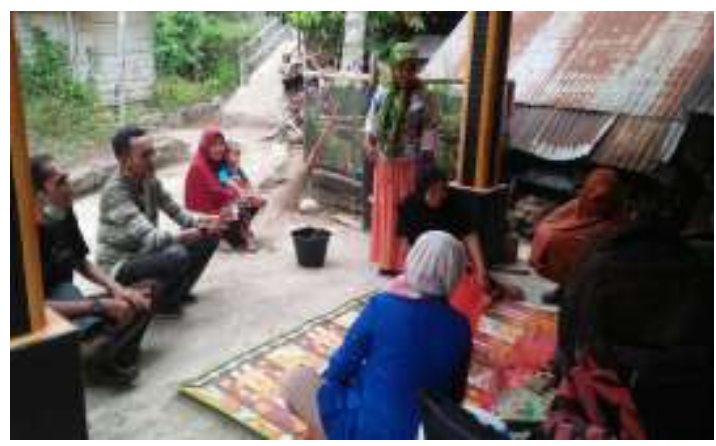

Gambar 3. Diskusi dengan Pengrajin Mengenai Kegiatan yang akan dilaksanakan

Setelah kegiatan diskusi dilaksanakan, maka dilanjutkan dengan demonstrasi dan mencontohkan kepada pengrajin bagaimana proses pembuatan produk. Hal ini dimulai dengan membuat desain motif yang akan diterapkan ke produk gerabah tersebut. Beberapa motif yang bisa menjadi pilihan dalam desain ini dibuat dikertas HVS A4 kemudian diterapkan ke media gerabah. Sebelum membuat sket desain di gerabah, produk tersebut harus diberi cat dasar terlebih dahulu. Hal ini bertujuan untuk memudahkan dalam membuat sketsa desain dan juga memberi nilai estetika. Warna cat dasar bisa 
dipilih dari warna terang atau agak gelap tergantung desain yang direncanakan. Selain itu dalam membuat motif, tentunya harus mempertimbangkan bagaimana komposisi motif pada bidang yang ditempati. Hal ini tentunya bertujuan untuk membuat desain motif yang lebih menarik dan cocok pada bidang yang ditempatinya. Setelah desain ditentukan, maka dilanjutkan dengan memindahkan desain tersebut ke gerabah. Hal ini bisa dilakukan secara langsung dengan mendesain diatas gerabah agar peserta terbiasa dalam mendesain di permukaan yang cembung. Pembuatan sketsa desain pada gerabah dilakukan dengan menggunakan pensil dengan memperhatikan komposisi dan bidang.

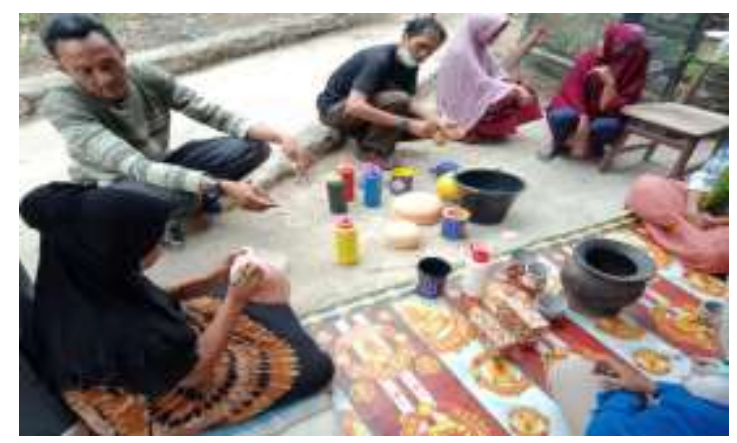

Gambar 4. Membuat Motif pada Gerabah

Setelah sketsa dari motif tersebut siap, maka dilanjutkan dengan mewarnai menggunakan kuas cat air. Pada kegiatan pewarnaan ini peserta harus memahami juga bagaimana cara membuat warna yang diinginkan. Hal itu karena cat yang digunakan hanya ada lima warna yaitu merah, biru, kuning, hitam dan putih. Dari lima warna tersebut bisa menghasilkan warna apa saja yang diinginkan dengan cara mengaduk warna. Pengadukan bisa dilakukan di palet aau gelas plastic yang telah disediakan. Selain itu pemilihan warna juga harus mempertimbangkan warna dasar dari gerabah yang telah di cat. Jika warna dasar gerabah tersebut adalah warna terang, maka warna dari motif sebaiknya dominan warna gelap, begitu juga sebaliknya. Hal ini bertujuan untuk menonjolkan warna dari motif yang akan diwarnai.

Setelah proses pewarnaan motif dengan menggunakan kuas selesai, maka dilanjutkan dengan proses pencantingan motif untuk memunculkan karakter batik dari desain tersebut. Proses pencantingan dengan menggunakan canting batik yang diberi cat akrilik. Pada proses pencantingan ini, motif yang di canting diwarnai dengancara digoreskan atau hanya dititik saja sehingga seperti motif batik pada umumnya. Pencantingan tersebut dilakukan pada motif utama dan diantara motif tersebut diberi isen-isen seperti motif batik pada umumnya. Penggunaan canting dalam pewarnaan inilah yang nantinya akan memunculkan karakter batik dari produk yang diwarnai.

Setelah kegiatan pencantingan selesai maka dilanjutkan dengan pemeriksaan akhir yaitu mengecek keseluruhan warna motif dan penerapannya. Hal ini bertujuan untuk memastikan warna motif sudah cocok dan tak motif yang belum diwarnai. Setelah seluruh motif diwarnai dan diberi isen secara merata, maka produk diangin-anginkan terlebih dahulu sampai keseluruhan cat mengering. Setelah cat kering maka dilanjutkan dengan proses finishing akhir yaitu memberi pengkilat dengan clear glossy. Pemberian clear glossy selain untuk memberikan efek berkilau, juga untuk melindungi lapisan cat agar tak mudah tergores.
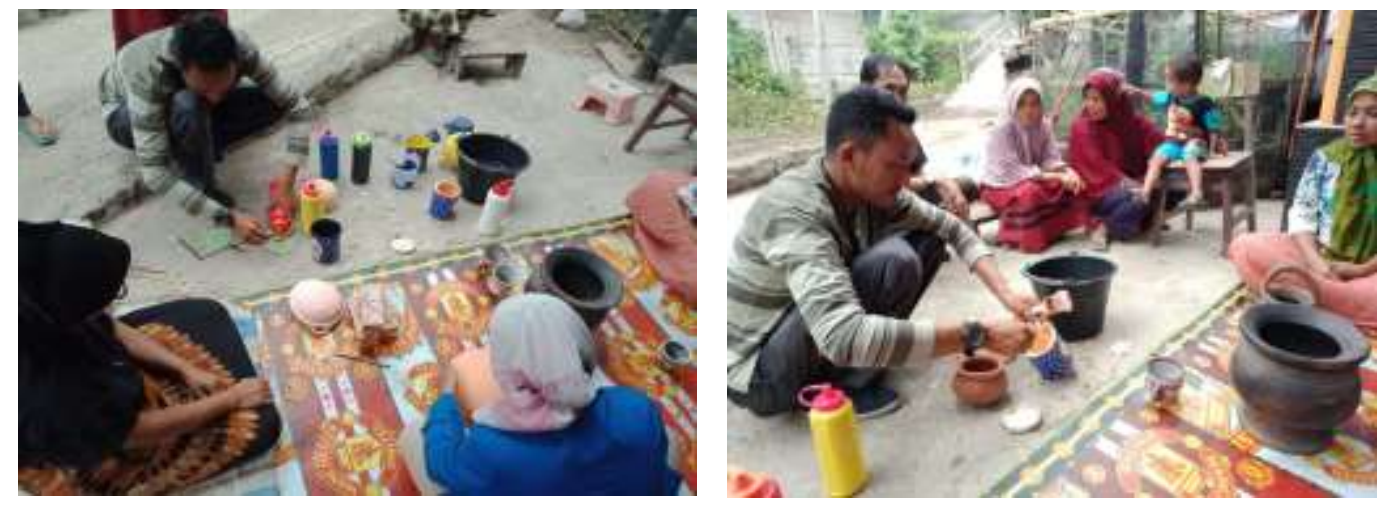

Gambar 6. Pengadukan Warna Cat 

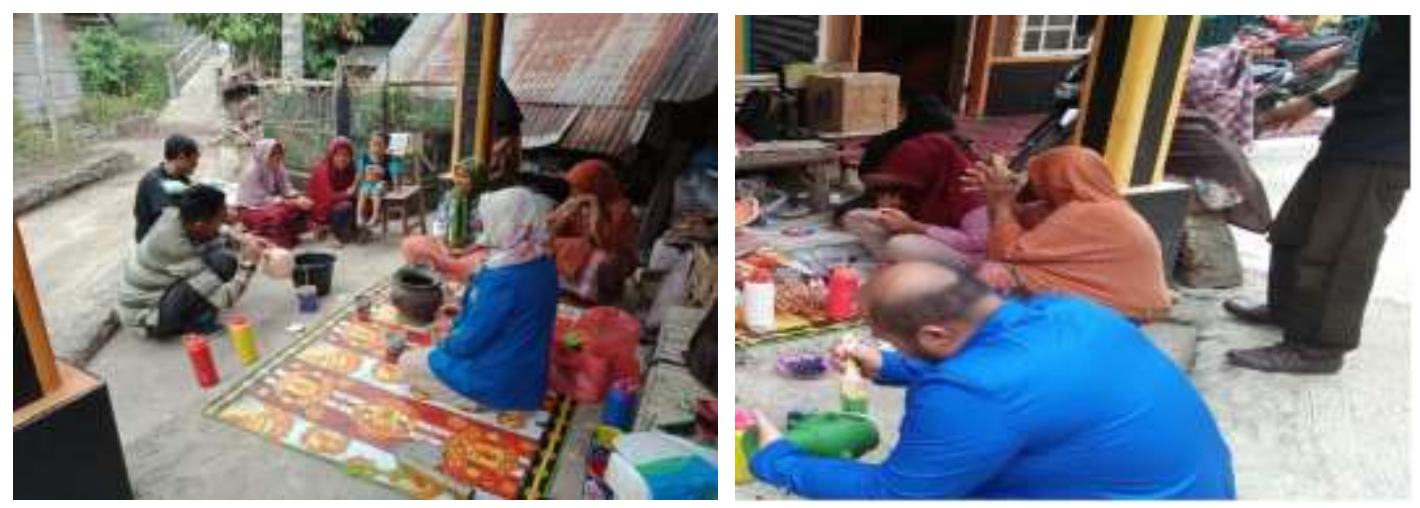

Gambar 7. Penguasan Cat Dasar Untuk Gerabah
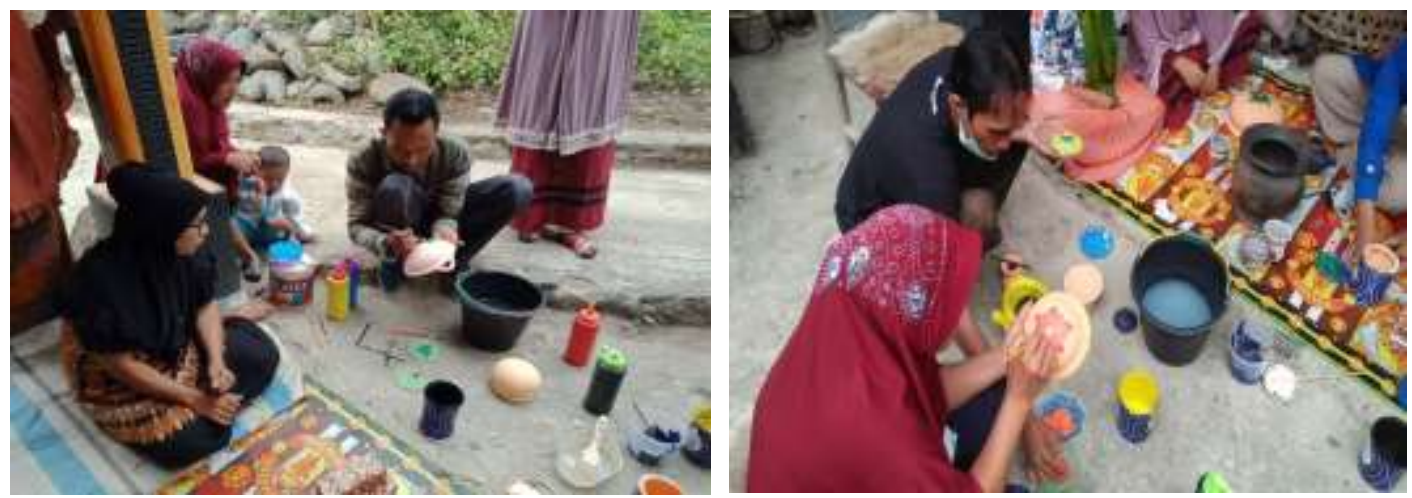

Gambar 8. Pewarnaan Motif dengan Menggunakan Kuas
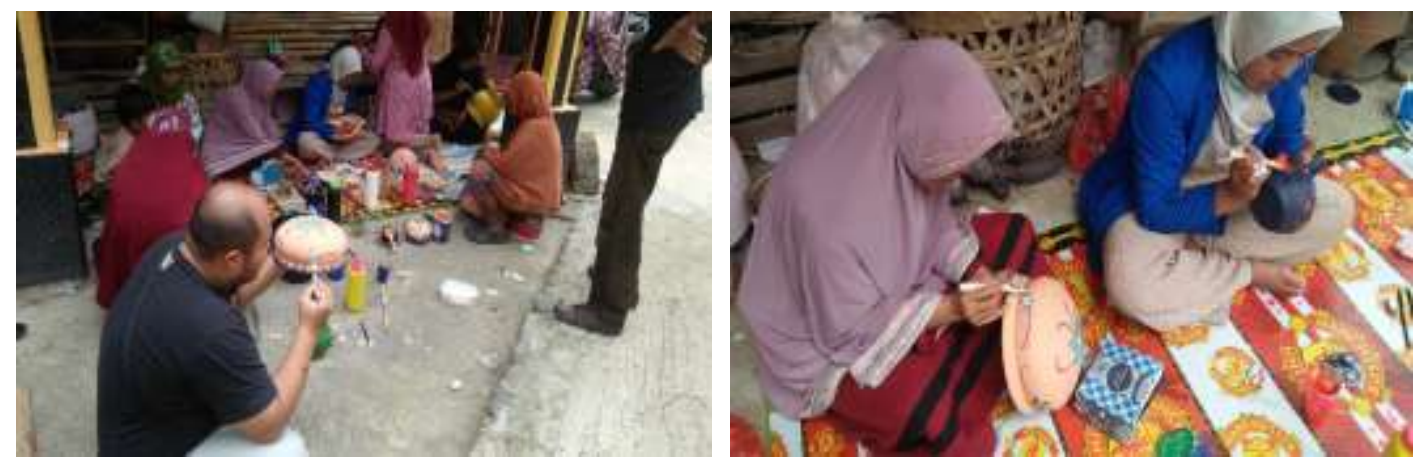

Gambar 9. Membuat Karakter Batik pada Motif dengan Menggunakan Canting

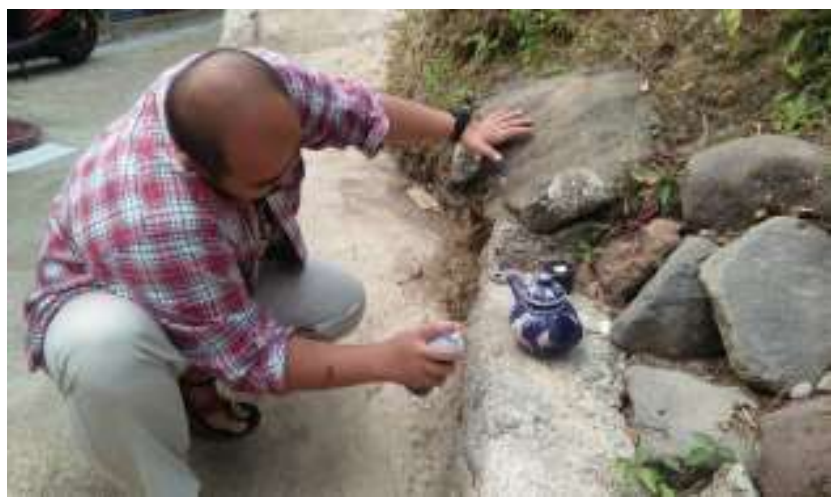

Gambar 10. Finishing dengan Menggunakan Clear Gloss 

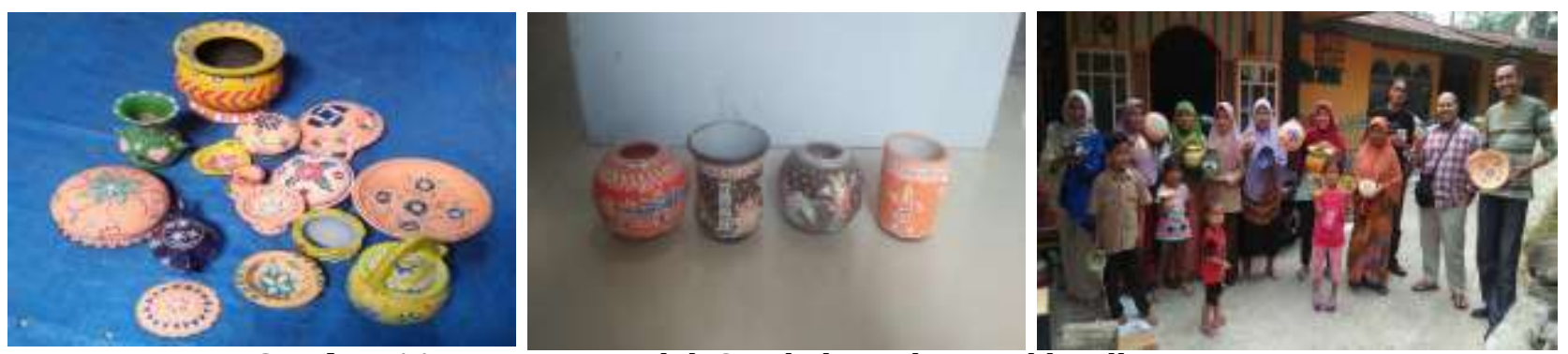

Gambar 11. Beragam Produk Gerabah Batik yang dihasilkan Pengrajin

\section{KESIMPULAN}

Produk geraah Galogandang yang sudah hadir selama puluhan tahun nyatanya tidak menunjukkan peningkatan berarti seperti yang diharapkan. Hal ini dikarenakan produk gerabah yang dihasilkan kurang popular jika dibandingkan dengan produk sejenis dengan bahan plastic atau logam. Hal ini menyebabkan eksistensi kerajinan gerabah tradisional Galogandang menjadi terancam. Kegiatan pelatihan desain gerabah dengan menggunakan motif batik bagi pengrajin yang ada disekitar Galogandang bertujuan untuk meningkatkan popularitas produk gerabah dan juga penghasilan dari pengrajin. Hal ini dikarenakan harga produk gerabah yang dihasilkan pengrajin sangat murah. Selain itu pengrajin juga belum mengetahui bagaimana cara untuk meningkatkan nilai jual produk gerabah yang mereka hasilkan.

Dengan menghias produk gerabah tradisional menggunakan motif batik, maka produk tersebut akan mengalami perubahan fungsi. Produk yang biasanya digunakan sebagai periuk dan tempat makanan, sekarang didekorasi dengan menggunakan motif batik sehingga amenjadi lebih menarik. Produk gerabah tersebut nantinya akan menjadi souvenir yang menarik bagi wisatawan yang datang. Apalagi daerah galogandang tidak terlalu jauh dari pusat wisata Istano Basa Pagaruyung. Wisatawan yang datang berkunjung ke Pagaruyung, bisa diberikan souvenir menarik yaitu gerabah tradisional dengan motif batik. Motif batik yang dihasilkan dibuat dengan beragam bentuk dan ukuran dan juga mengembangkan desain motif khas Minangkabau.

Dengan munculnya produk gerabah dengan desain motif khas Minangkabau, maka produk ini akan menjadi souvenir andalan bagi wisatawan yang datang. Selain motif yang menarik, harga jual dari produk gerabah juga akan meningkat. Hal ini tentunya juga akan meningkatkan taraf ekonomi pengrajin. Selanjutnya diharapkan popularitas produk gerabah tradisional Galogandang juga akan terdongkrak dan disukai oleh konsumennya.

\section{DAFTAR PUSTAKA}

Amstrong. Michael. 1990. Manajemen Sumber Daya Manusia.. PT Elek Media Komputindo. Jakarta Mulyasa. 2006. Menjadi Guru Profesional. Remaja Rosdakarya. Bandung.

Prawira, N. Ganda \& Dharsono. 2003. Pengantar Estetika dalam Desain Seni Rupa. Departemen Pendidikan Nasional. Bandung.

Wulandari, Ari. 2011. Batik Nusantara Makna Filosofis Cara Pembuatan Dan Industri Batik. CV Andi Offset. Yogyakarta. 